\section{Guidance of young people to activity, healthy nutrition and obesity awareness as a sport policy}

\section{Spor politikası olarak gençlerin sportif aktivitelere yönlendirilmesi, sağlıklı beslenme ve obezite farkındalı̆̆1}

\author{
Tamer Acaroğlu ${ }^{1}$ \\ Tekin Çolakoğlu ${ }^{2}$
}

\begin{abstract}
The research was conducted to determine the physical activity, nutritional behaviors and obesity awareness of young people between the ages of 16-27 in Ankara and to offer a new sports policy. Obesity awareness questionnaire consisting of 20 questions was applied to the participants. The original form consists of 23 questions and three sub-dimensions; 1) Obesity awareness (8 questions), 2) Nutrition subdimension (7 questions) and 3) physical activity sub-dimensions (8 questions). As a result of the detailed analyzes, it was determined that the sample was not evenly distributed in terms of education level. Educational background and its sub-dimensions were examined by Kruskal Wallis $\mathrm{H}$ test. As a result of the analyzes, it was found that women were in majority. In addition, it was found that the results of the analysis did not show statistically significant difference in the sub-dimensions and overall scale according to the age of the participant. When the results of one-way analysis of variance according to occupational classification of the participants were examined, it was found that there was no
\end{abstract}

\section{Özet}

Araştırma Ankara ilinde 16-27 yaş arası bireylerin fiziksel aktivite, beslenme davranışları ve obezite farkındalıklarını belirlemek ve buna ilişkin bir spor politikası önerisi oluşturmak üzere yapılmıştır. Katılımcilara 20 sorudan oluşan obezite farkındalık anketi uygulanmıştır. Ölçeğin orjinal formu 23 madde oluşmaktadır. Üç alt boyuttan oluşan ölçeğin alt boyutları; 1) Obezite farkındalığ1 (8 madde), 2) Beslenme alt boyutu (7 madde) ve 3) fiziksel aktivite alt boyutlarından (8 madde) oluşmaktadır. Yapılan detaylı analizler sonucunda Eğitim seviyesi bakımindan örneklemin alt gruplarda dengeli dağılmadığ1 tespit edilerek eğitim seviyesi değişkeninin ölçek genelinde ve alt boyutlarındaki durumu Kruskal Wallis h testi ile incelenmiştir. Yapılan analizler sonucunda obezite farkındalığ1 alt boyutunda cinsiyete göre kadınlar lehine anlamlı fark olduğu görülmüştür. Ayrıca katılımcıların yaş değişkenine göre analiz sonuçlarının alt boyutlarda ve ölçek genelinde istatistiksel açıdan anlamlı bir farklılık göstermediği tespit edilmiştir. Katılımcıların meslek kategorilerine göre tek yönlü varyans

\footnotetext{
${ }^{1}$ tmracaroglu@gmail.com (iD) Orcid ID: 0000-0002-5973-4282

2 Assoc. Prof. Dr., Gazi University, Sport Sciences Faculty, Department of Sport Management, tcolakoglu@gmail.com (iD) Orcid ID: 0000-0002-4250-6769
} 
Acaroğlu, T., \& Çolakoğlu, T. (2020). Spor Politikasi olarak Gençlerin Sportif Aktivitelere Yönlendirilmesi, Sağlıklı Beslenme ve Obezite Farkındalığ1. Journal of Human Sciences, 17(1), 340-358. doi:10.14687/jhs.v17i1.5944

statistically significant difference in obesity awareness physical activity sub-dimensions and scale in general. However, it was found that there was a statistically significant difference between the group averages according to occupational categories in the nutrition subdimension. Significant difference was observed between public employees and students and it was aware than students. When the results of one-way analysis of variance according to income categories were examined, it was found that there was a statistically significant dimension according to occupational classification. The ones who have over 5.500tl monthly income were in majority. There was no statistically difference in the analysis according to BMI values. According to the results of the analysis based on the level of education, no statistically significant result was found. Increasing awareness of individuals about physical activity and obesity is crucial in preventing nutrition and obesity, besides more comprehensive plans and policies are required to be developed in order to adapt this knowledge into lifestyle.

Keywords: Sport policy, nutrition, physical activity, obesity awareness.

(Extended English summary is at the end of this document) analizi sonuçları incelendiğinde obezite farkındalık, fiziksel aktivite alt boyutlarında ve ölçek genelinde istatistiksel açıdan anlamlı bir farklllık göstermediği tespit edilmiştir. Bununla birlikte beslenme alt boyutunda meslek kategorilerine göre grup ortalamaları arasında istatistiksel açından anlamlı bir farklılık bulunduğu görülmüştür. Anlamlı farkın kamu çalışanları ile öğrenciler arasında ve kamu çalışanlan lehine gerçekleştiği görülmüştür. Gelir kategorilerine göre tek yönlü varyans analizi sonuçları incelendiğinde obezite farkındalık boyutunda meslek kategorilerine göre grup ortalamaları arasında istatistiksel açından anlamlı bir farklıllı bulunduğu görülmüştür ve bu farkın aylik 5.501 TL geliri olan bireyler lehine olduğu tespit edilmiştir. BKİ değerlerine göre yapılan analizde ise istatiksel açıdan anlamlı bir fark bulunamamıştır. Yine eğitim seviyelerine göre yapılan analiz sonucuna göre de istatiksel açıdan anlamlı bir fark bulunamamıştur. Bireylerin Fiziksel aktivite ve obezite konusunda farkındalığının arturılması beslenme ve obezitenin önlenmesinde önemli olmakla birlikte, edinilen bilgilerin yaşam tarzına adapte edilebilmesi için daha kapsamlı plan ve politikaların geliştirilmesi gerekmektedir.

Anahtar Kelimeler: Spor politikas1, beslenme, fiziksel aktivite, obezite farkındalığı.

\section{Giriş}

Spor ve sağlıklı yaşam 20. yy sonlarından beri sürekli yinelenen değişen ve gelişen bir kuram olarak karşımıza çıkmaya devam etmektedir. Son yıllarda ise önem kazanan bu konu artık sosyal yaşamın, bilimin hatta siyasi politikaların dahi konusunu oluşturmaktadır. Tüm bunların en büyük sebebi ise genel hareketsizlik eğilimi yanlış beslenme ve bunu destekleyen faktörlerdir. Hızla yayılan obeziteye karşı günümüzde çeşitli ülkelerde çeşitli çözüm önerileri geliştirilmiş olup bunlarla mücadele içinse farklı politikalar üretilmiş ve hayata geçirilmiştir. (Sunay, 2003)

Obezite öncelikli tanımı ile tipik olarak çevresel, genetik ve geleneksel faktörler gibi farklı etkileşimler sonucunda vuku bulmaktadır (Önder ve Aydın, 2013 ). Obezite bazında yapılan çalışmaların birçoğunda obezitenin fizyolojik tarafina odaklanılıp psikolojik faktörler göz ardı edilmiştir. Toplumda obezite farkındalığını ölçmek için ve bir spor politikası olarak obezite oranının yükselmesine engel olmak amacıyla birtakım çalışmalar yapılmıştur. Odea ve Wilson Avusturya'da 4441 öğrenci ile yaptıkları tetkiklerde ise gençlerde kahvaltı itiyati ve sosyo ekonomik durumun vücut kitle indeksi üzerine etkilerini incelemişler. $\mathrm{Bu}$ ve bunun gibi araştırmalardan da anlaşıldığ1 üzere obezite ve fiziksel aktivite üzerine eğinmek suretiyle tutarlı ve dengeli adımlar atılmaya çalışılmışıı (Aydın, Demir ve Yetim, 2007). Sporun psikolojiye olan faydaları hakkında yapılan sayısız çalışmada spor, sağlıklı yaşam ve beslenmenin ayrılmaz bir yaşam üçlüsü oluşturduğunu dile getirebiliriz. Milletlerin ve ülkelerin birbirleriyle kıran kırana çekişme durumunda bulundukları 
Acaroğlu, T., \& Çolakoğlu, T. (2020). Spor Politikasi olarak Gençlerin Sportif Aktivitelere Yönlendirilmesi, Sağlıklı Beslenme ve Obezite Farkındalığ1. Journal of Human Sciences, 17(1), 340-358. doi:10.14687/jhs.v17i1.5944

günümüz global dünyasında bilimsel, kültürel ve teknolojik ve bir o kadar da önem arz eden iktisadı sahaların yanında sporda da devri yakalamak çok mühim bir misyon ve maksat olmalıdır.

Avrupa'nın ve Amerika'nın en taze nüfus ortalamasına malik ülkemizde gençlerimizi ve çocuklarımızı spora ne denli yönlendirebilirsek o denli sağlıklı nesiller oluşturabiliriz (Sunay, 2003). Tüm bu çalışmalar ışı̆̆ında,gençlerin sportif dallara ve fiziksel aktivitelere yönlendirilmesi beslenme alışkanlıklarının takibi ve obezite ile mücadele biçimleri bir spor politikası şeklinde ve çerçevesinde sistemli ve detaylı bir çalışma ile yürütülerek başarılı bir proje sonucunda istenen verilerin (sonuçların) elde edilme ihtimal düzeyleri oldukça yükselmektedir. Tüm bu sorunların devlet politikası olarak yürütülmesi ile düzenli spor yapan gençler daha sistemli bir biçimde motive edilmiş olacak ve mental olarak rahatlayan gençler hem sağlıklı beslenerek aynı zamanda fazla kilolarını atarak toksinlerden arınmıs olacaklardır. Fazla kilolarından kurtulan gençlerin sporla mental rahatlama neticesinde daha verimli ve başarılı bireylere dönüşmesi ise aşikardır. $\mathrm{Bu}$ görüş ve düşünceler ışığında ülkemizde spor politikalarının oluşturulmasına katkı sağlarken, ülkenin yadsınamaz gerçeklerini ve olanaklarını daha da zorlayarak geleneksel koşulları ve süre gelen uygulamalarımızı da göz önünde bulundurmamız gerekmektedir. Sporun ülke genelinde ve özelinde yaygınlaştırılmasına için belli başlı çabaları harcarken, özellikle bireysel yarışma sporlanı öncelikli olmakla birlikte takım halinde yarışma spor dalları için neyin, ne şekilde nerede, ne şartlarda yapılacağı belirlenmelidir. Spor kollarında önceliklerin sıralamasından, spor kollarındaki icraatlar için esas kurallara, tesis yapımından tutunda, salonların ayarlanması ve özel zeminler ve stadyumların yapımından envanter seçimine kadar, personel ve eğiticilerin eğitimine ve antrenör yetiştirilmesinden öğretimine kadar ilkeleri ortaya koyan bir spor politikası ortaya konulmalıdır. (Sunay, 2003).

\section{Spor Politikas1}

Spor politikası denince; sporun ele alınışı, esas ve amaçları, bu amaçlara ulaşma usul ve metotlan, altyap1, tesis, araç-gereç ve eğitim-öğretim anlayışı, ulusal ve uluslararası düzeyde spora bakış açısı, sporun örgütleniş ve uygulanış felsefesi akla gelmektedir (European Commission ,2007b). Türkiye de spor politikalarının amaçlarını; ulusal sporun örgütlenmesi, güçlendirilmesi ve sporcu gelişiminin yönlendirilmesi olarak sıralamak mümkündür (Acar,1993; Sunay, 2003).

Spor siyasetin bir ürünü, malzemesi olamayacak kadar kutsal bir değerdir. Bu anlamda partiler üstüdür. Sporun yegane politikası topluma ihtimamdır. Ülkemizde özellikle genç nüfus diye tabir edilen 12-24 yaş aralığ ciddi bir paya sahip hale gelmiştir. Tüm dünya genelinde ülkeler azalan genç ve dinamik nüfuslarını yeniden yükseltmeye çaba harcarken, bizim bu genç ve güçlü nüfusu 2020' li yıllara taşımak temel hedefimiz olmalıdır. Hükümetlerin, programlarında spora yer vermeleri ile oluşturulan spor politikaları, sporun gelişimine yön vermesi açısından önemlidir (Sunay, 2003).

Eğitim öğretim kurumları Okullar, sporu eğitimde önemli ve iletişimi düzenleyen bir araç olarak benimsemişlerdir. Politikacılar özellikle seçim kampanyası döneminde, vatandaşta pozitif bir fikir oluşturabilmek adına spor organizasyonlarında ve özellikle kazanana madalyasını takdim etmek üzere madalya törenlerinde görünür olmaya ihtimam gösterir olmuşlardır. Hükümetler toplumsal çözülmeyi önlemek, insanların anarşi devlete ve anayasal düzene ve teröre yönelmesini engellemek onları toplumda huzurlu bireylere çevirebilmek için sporu önemsemeye, spor tesis ve organizasyonlarına yatırım yapmaya başlamışlardır Bu aynı zamanda sporun sosyal bütünleşme aracı olduğunun da kanıtıdır. Böyle bir gücün farkına varan Avrupa Birliği ise kuşkusuz bu alanda hedefler koymuştur. AB sağlıkl, hümanizme dayalı, siyasi ve ekonomik anlamda istikrarlı bir birlik Avrupa Birliği oluşturmayı hedeflemektedir. Bu minvalde 1 Kasım 1993, Maastricht, Hollanda'da kurulan bu sivil birlik temel konulardan birisini $\mathrm{AB}$ üyesi ulusların vatandaşlarının sağlık durumları ve buna bağlı türevler oluştururken, diğer bir husus ise farkllıklarını birlik içerisinde tümevarıma ulaştıran bir Avrupa toplumunun ve halklarının oluşturulmasıdır. Sporun sosyal bütünleşme aracı olarak oynayabileceği rol önem taşımaktadır. Spor, çeşitli aktörlerin etkileşimde bulunması, ağlar 
Acaroğlu, T., \& Çolakoğlu, T. (2020). Spor Politikasi olarak Gençlerin Sportif Aktivitelere Yönlendirilmesi, Sağlıklı Beslenme ve Obezite Farkındalığı. Journal of Human Sciences, 17(1), 340-358. doi:10.14687/jhs.v17i1.5944

oluşturması bu ağlar sayesinde ve işbirlikçi/rekabetçi ilişkiler geliştirmesi için ortam sağlamaktadır (Ostlinning \& Freya Elisa, 2011).

\section{Türk Spor Politikas1}

90 yıllarla beraber sporda altın çağına yürüyen Türkiye 2020 'li yıllara maalesef kısmen başarıdan uzak bir giriş yapmıştır. Kısmen yanlış eğitim biçimleri, kısmen öğretim hayatında ki eksikler müsabaka yer ve zamanında meydana gelen aksakliklar ve ekonomik buhranlar ve finansal kaynaklarda yaşanan sıkıntılar kamp çalışmaları da dahil yurt içi ve dışı müsabakaların iptali ile sonuçlanmıştır (Sunay, 2003).

Ayrıca olimpiyatlara talip olmadan evvel buna talip olan ülkenin kuşkusuz ilk yapması gereken olimpiyatları düzenleyeceği ve müsabakaların gerçekleşeceği tesisleri bir an evvel bitirmesidir. Fakat durum bu haldeyken, spor yatırımları için en azından yüzlerce milyon bütçe talep eden spor federasyonlarına sadece 60-70 milyon dolarla anılan bir bütçenin ayrılmış olması sporun acı hakikatleri arasındadır. 2019 başlarında Türkiye'de yaklaşık 16.000 dolaylarında spor tesisi veya kompleksi bulunmaktadır. Bunların onarım-bakımına ait giderler buna haiz ayrilan ancak bu ödenek ile karşılanabilir. Türkiye'nin ve AB'nin büyüyen ve farklılaşan koşulları artık farklı türevde spor politikalarını zaruri hale getirmektedir. Hedef sporun toplumlarda kabul görüp yaygınlaşması ve her yaş grubunun spora olan ilgi ve alakasını artırarak spora eğimli bir medeniyet kurmaktır. Meğerki günümüzde spor, küresel sulhun, anlayış ve teşriki mesainin simgesi olup, bunun anında sadece bireyin vücut sağllğ1 fiili olmaktan ziyade,adeta evrensel bir manaya bürünmüştür (Acar, 1993).

Ayrıca spor, sağlıklı nesillerin yetiştirilmesi ve böylece çağdaş toplumların yaratılmasında eğitimin ayrılmaz bir parçasıdır. Spor daha bilinçli bireylerin yetişmesine imkan sağlarken, sosyal ve mental olarak rahatlayan gençler bu minvalde daha başarllı ve azimli olacaklar bu sayede hedeflerine daha kolay ulaşabileceklerdir. (Yetim, 2000)

1982 Anayasası'nın 58 ve 59. maddelerinde gençliğin kötü alışkanlıklardan korunması ve her yaştaki Türk vatandaşlarının beden ve ruh sağlığını geliştirmek için tedbirler alınması yönünde gençlik ve spor, devlet politikası olarak güvence altına alınmıştır. Bu hizmetlerin görülmesinde belediyeler de önemli görevler üstlenmektedir (Kurtipek, 2019) Son zamanlarda çocuklar ve gençler için inşa edilen spor okulları ve buna ek olarak yapılan çok amaçlı ve sabit amaçlı spor tesisleri bunlardan bazılarıdır. Yine belediyelerin sporun her alanında kurmuş oldukları kulüpler bazında spora verdikleri destekte bunlardan biridir. Bu ve bunun gibi gelişmeler arttıkça olumlu dönüşleri ve sonuçları kuşkusuz artacaktır.

Spor siyasetin bir ürünü, malzemesi olamayacak kadar kutsal bir değerdir. Bu anlamda partiler üstüdür. Sporun yegane politikası topluma ihtimamdır. Ülkemizde özellikle genç nüfus diye tabir edilen 12-24 yaş aralığ ciddi bir paya sahip hale gelmiştir. Tüm dünya genelinde ülkeler azalan genç ve dinamik nüfuslarını yeniden yükseltmeye çaba harcarken, bizim bu genç ve güçlü nüfusu 2020' li yıllara taşımak temel hedefimiz olmalıdır. Hükümetlerin, programlarında spora yer vermeleri ile oluşturulan spor politikalan, sporun gelişimine yön vermesi açısından önemlidir (Güler, 2005). Hedef sporun farklı yaş grubunda ki bireylerinde sahiplenmesi ile farklı bir güce ve boyuta ulaşmasıdır. Öyle ki günümüzde spor, tek başına olmasa da dünya barışının, anlayış ve hoşgörünün bunu neticesinde siyasi ve sosyal işbirliğinin sembolü olup, bununla beraber sadece bireyin vücut sağlığ1 fili dışında, adeta toplumsal bir önem kazanmıştır. Tüm bunlar birlikte düşünüldüğünde dünyanın ve Türkiye'nin gelişen ve değişen siyasi ve sosyal şartları artık yeni bir spor politikasını da zorunlu kilmaktadır. (Acar, 1993) Fakat tarihsel süreçte çizilen spor politikaları geçmişimize ve Türk sporunun bugün bulunduğu konuma bakılacak olursa, mevcut politikanın ülkemizin spor alanındaki ihtiyaç ve beklentilerini karşılamadığı açıktır. Bunun başlıca nedeni, spor politikalarında teorik bir zeminin yokluğu ile mevcut politikanın hayata geçirilişinde yaşanan aksaklıklardır.

Ülkemizde sağlık harcamalarının Yıllık Gayri safi milli harcamalardaki payı artmış gibi görünse de nüfus artışılla doğru orantılı olduğu düşünülürse artışı aşırı bir ivmeyle olmadığı görülecektir. Buna rağmen bizim gibi gelişmekte olan ülkeler için bu harcamalar ciddi kalemler oluşturmaktadır. Burada en başından beri asıl anlatulmak istenen husus ise sağlık harcamalarının gerekli beslenmeye 
dikkat edilmesi ve fiziksel aktivitenin artırılması olarak ise iş gücü verimliliğinin mutlak surette artacağına ilişkindir. Gerekli ve yeterli bir beslenme çizelgesi ve fiziksel aktivite ile beraber ciddi sağlık harcamalarında da azalma olacağı aşikardır (Hartung, Stadeler, Grieshaber, Keller, Jahreis, 2010).

Yine başka bir yönden Spor, evrensel öneme sahip bütünleştirici bir araçtır. Spor, milletlerarası politika açısından aslında çoğu defa göz ardı edilen pek mühim bir ehemmiyete sahiptir. Spor etkinlikleri farklı ülkelerden, farklı coğrafyalardan kültürlerden, farklı ırklarda etnik kökenlerden, dinlerden bireyleri uhrevi ve iyilik maksatlı çerçevesinde bir araya getirmektedir. Sporun insanlar ve cemiyetler arasında meydana getirdiği ortak dil, kültürel ve göreneksel farklılıkların ürettiği engellerin üstünden gelmek için farklı sosyal ortamlar meydana getirirken insanlar ve devletlerarasında iletişim sağlanmasını kolaylaştırmaktadır. Bu mahiyette sporun ekonomik, sosyal türevlerinin yanında siyasi türevlerinden de söz edilebilmektedir. Özellikle yakın bir gelecekte sporu bir milletlerarası politik siyasi bir araç olarak ele alan $\mathrm{AB}$, sporun politik yanını dışa dönük temaslarına tümleşik etmektedir (Fişek, 1980).

\section{Fiziksel Aktivite}

Yaşamımızın her aşamasında hareket vardır. Koşmak, sıçramak, bisiklete binmek, yürümek, yüzmek, merdiven çıkmak, oturmak, kalkmak, kol, bacak, baş ve gövde aktiviteleri gibi vücudun esas aktivitelerinin tamamını ya da bir bölümünü kapsayan çeşitli spor dalları, dans, egzersiz, oyun ve gün içerisinde yapılan diğer fiziksel aktiviteler olduğu kabul edilmiştir (Doğan, Mende, Akcan, Tepe, 2016).

Diğer pek çok faydasının yanında fiziksel hastalıkları da azalıtı, koroner kalp hastalıkları riskini azaltır ve yine kan dolaşımını iyileştirerek, iyi kolesterolu arttırarak kalp hastalığı riskini azaltır, kan basıncını düzenler, kalp ve akciğer hastalıklarına karşı dayanıklılığını arttırır. Çocuklarda olumlu alışkanlıkların daha da geliştirilmesini ve gelecekte çocukların sağlıklanının korunmasını sağlar. Denge kurmayı ve dengede kalmayı kolaylaştırır, kas gelişimini sağlar, refleks ve reaksiyon suresini kısaltmak gibi birçok faydası vardır. Fiziksel aktivitenin pek çok hastalık için önleyici faktör olduğu sayısız epidemiyolojik araştırmada kesinleşmiştir. Ayrıca önleyici rolü ile birlikte fiziksel aktivite birçok hastalı̆̆ın tedavisinde tavsiye edilmektedir (Altay, 2007)

Fiziksel aktivitenin düzenli oluşunun insan sağlığına yararları oldukça büyüktür. Hareketsizliğin kemik döngüsüne ve gelişimine olumsuz etkisi sebebiyle, çocukluktan yetişkinliğe geçerken bu geçiş döneminde kemik kütlesinin yeterli olmasında kalsiyum alımının önemi ciddi olduğu kadar fiziksel aktivite türlerinden kemiklerin ve kasların gerilmesine ve kasılmasına etki edecek türde aktiviteler yapılması da bilhassa önem arz eder (Gür, 2000) Çocukluk çağında düzenli aktivite alışkanlığ1 edinmenin yetişkinlik çağında da süreceği varsayımı, aktivitenin çocukluk çağındaki etkisi oldukça büyüktür.

\section{Beslenme ve Obezite Farkındalığı}

Beslenme: insanların sağlıklı bir büyüme ve gelişme sürecini olumlu yönde etkileyen ve üretkenliklerinin devamlılığını sağlayan ve bunun yanında daha uzun ve sağlıklı bir yasam süreci geçirmeleri için gerekli besin öğelerinden yeterli ve sağlığa zararlı hale getirmeden alarak vücutta kullanilmasidır.

Beslenmenin fizyolojik bir olay olmasının yanında psikolojik ve sosyolojik bir durum olduğu unutulmamalıdır. Aksi halde obezite kavramı tek başına var olur obezite farkındalı̆̆ kavram olarak mevzu bahis bile olmazdı. Sağlıklı bir toplumun kendine dikkat eden sağliklı kişilerden oluşması gerekmektedir. Bireylerin sağlıklı olması ise o toplumun gelişmesi büyümesi hedeflerine ulaşması ve muasır medeniyetler seviyesine ulaşmasından devamında rol oynamaktadır. Sağlıklı yaşamın piramitte ilk basamağı ise doğru beslenmedir. Çocukluk dönemindeki beslenmenin büyüme ve gelişmede rolünün yanında birde gelecekteki hayat düzeninde bireyin sağlık durumunun da belirleyicisidir. Beslenme hiçbir zaman sadece karın doyurma olarak algılanmamalıdır (Karasu, 2006). 
Acaroğlu, T., \& Çolakoğlu, T. (2020). Spor Politikasi olarak Gençlerin Sportif Aktivitelere Yönlendirilmesi, Sağlıklı Beslenme ve Obezite Farkındalığ1. Journal of Human Sciences, 17(1), 340-358. doi:10.14687/jhs.v17i1.5944

Ülkemizde beslenme bilgisini arttırmak için ilköğretimlerde çeşitli derslerde ve ortaöğretim düzeyinde sağlık bilgisi gibi derslerde beslenme bilgisi verilmeye çalışllmaktadır (Kuşgöz,2005) Yeteri kadar beslenmelerine rağmen doğru besinleri almamaları sebebiyle insanlar, genelde aynı besin grubunun veya benzer besin öğelerinin tüketilmesi, alınmayan besin öğesinin vücuttaki görevinin yerine getirilmemesi sonucunu da doğurur. Bu da sağlık açısından eksi bir etki yapacaktır. Bu durumun ortaya çıkmasına da dengesiz beslenme denir (Kuşgöz, 2005) Beslenme sorunları ile başa çıkmada insanların en büyük silahı beslenme bilgisi eğitimidir. Ülkemizde yapılan çalışmalarda dengesiz beslenmeden özellikle gelişme döneminde olan çocuklar, hamile kadınlar ve sütannesi olan kadınların etkilendiği görülmüștür (Karasu, 2006).

Dengesiz bir beslenmenin yanında doğru bir beslenme ile ergenlerin gerek fiziksel gerekse de zihinsel gelişimi pozitif yönde etkilenebilir. Kişinin gelecekteki sağllk durumu, psikolojik durumu ve hatta çalışma kapasitesini adolesan dönemdeki beslenme alışkanlıklarından etkilenmektedir. Beslenmenin değerlendirilmesinde antropometrik ölçümlerin kullanılması ile daha doğru anlaşılabilir. Kişinin VKE düzeyi ile kiloluluk yağ oranı ve obezlik, zayıflık gibi durumları daha rahat tespit edilebilir (Gümüş, 2009)

Gelişimi bir bütün olarak ele almak gerekirse evre evre incelediğimizde, adolesan ve çocukluk dönemlerinde vücudun çatısını oluşturan iskelet sistemi gelişmektedir. Bu gelişimi sağlıklı bir şekilde sağlayabilmesi için kemik yapısının gelişmesinde, doğru beslenmenin rolü çok fazladır. Özellikle süt ve süt ürünlerinden alınan Kalsiyum ve diğer minerallerin doğru şekilde alınmaması bu gelişimi olumsuz etkileyebilir. Bazı çalışmalarda meyve, sebze, süt ve süt ürünleri tüketimi arasındaki ilişki incelenmiştir. Yapılan çalssmalar sonucu kemik gelişiminde süt ve ürünlerinin tüketilmesinin iskelet yapının gelişiminde etkili olduğu görülmüş, bazı çalışmalarda ise kızların kemik gelişiminin erkeklerden geride kaldığ1 tespit edilmiştir (Gümüş, 2009; Karasu, 2006).

Beslenme yaşamın devamı için olmazsa olmaz bir eylemdir. Daha öncede anlattuğımız gibi beslenme sırf yeme içme filini değil ona karşı bakış açısını evveliyatı zamanlaması ve içeriği ilen bir bütündür. Dengesiz beslenme bazen yetersiz miktarda besin alınması ile bile obeziteye neden olabilir. Çünkü mühim olan besinin içeriği ve zamanlamasıdır.

Obezite her yaş dönemde tespit edilebilen bir sağlık sorunudur. Adölesanlarda obezite yönünden rizikolu dönemlerin olduğu bu zaman dilimlerinde ihtimal yüzdelerinin daha fazla olduğu aşikardır, yapılan araştırmalar sonucu ortaya çıkmıştır. Özellikle ilk altı ayda obezite daha fazla görülebilir. Çocuğun eylemlerinde fazlalaşma ve emekleme sonrası desteksiz yürüme ile beraber 1 yaşından sonra obezite oranı giderek düşer (Günoz, 2001). Şişman ve hareketsiz bebeklerin 5 yaşındayken obezite olma olma riski, ideal kilodaki bebeklere göre karşılaştırllinca 5 kat ve daha fazla bulunduğu tespit edilmiştir. Çocukluk dönemi yaş grubunun ikinci dönemi 4-11 yaşları arasıdır. Bu çağdaki şişmanlık daha sonraki çağlarda da devam etme durumu açısından yüksek risk taşır. 3 . riskli dönem adölesan dönemidir. Vücuttaki yağ dokusu bu dönemde kızlarda artış gösterirken, erkek çocuklarında ise azalır. Puberte döneminden sonra ise yağ hücrelerinde artış meydana gelmez, sadece yağ hücrelerinin büyüklüğünde değişme meydana gelir (Güler, Altay \& Gönener, 2009).

Çeşitli ülkelerde insanların ortalama vücut ağırlığ1 ve obezite sıklığ1 giderek artmaktadır. Bu durum karsısında DSO "küresel obezite salgını" olarak ilan etmiştir. Obezite ile paralel olarak gelişen birçok hastalık ( diyabet, kalp hastalıkları gibi ) bizleri dünya boyutunda bir halk sağlığı krizi ile karşılaştırmıştır. Bunların yanında genetik ve çevresel faktörler de obezite salgınında rolü vardır (Sema, 2006) Araştırmamıza göre ise daha önemli olan husus gençlerin obezite olmasından ziyade bunun farkındalık düzeyleridir. Ülkemizde Spor ve dengeli beslenme üzerine kararlı ve ciddi bir politika olmamasına karşın farklı çalışmalar ve metotlar denenmiş ama istenen başarıya henüz ulaşılamamıştır. Buna binaen her geçen gün obezite ve sağlıksız vücut tiplerine sahip birey sayısı artmakta ve spordan uzak nesiller sporun mental rahatlığından kat be kat uzak kalmaktadırlar. İște bu sorunların ortak noktası olarak ise fiziken ve ruhen çökme eğilimine gelmiş olan çalışanların sağlık sorunları başlamakta buna bağlı genel iş gücü ve verim de ciddi düşüşler yaşanmaktadır, sporun psikolojiye olan faydaları hakkında yapılan sayısız çalışmada spor, sağlıklı yaşam ve beslenmenin ayrilmaz bir yaşam üçlüsü oluşturduğunu dile getirebiliriz. 
Acaroğlu, T., \& Çolakoğlu, T. (2020). Spor Politikasi olarak Gençlerin Sportif Aktivitelere Yönlendirilmesi, Sağlıklı Beslenme ve Obezite Farkındalığ1. Journal of Human Sciences, 17(1), 340-358. doi:10.14687/jhs.v17i1.5944

\section{Yöntem}

Bu bölümde araştırmanın modeli, evren ve örneklemi, veri toplama arac1, veri toplama süreci ve veri çözümleme tekniği açıklanmışır.

\subsection{Araştırmanın Modeli Evren ve Örneklem}

Ankara da 16-27 yaş arası bireylerin, fiziksel aktivite düzeylerini obezite farkındalık durumlarını sağlıklı beslenme düzeylerini belirlemek maksadıyla yapılmıştır, Bu araştırma nicel araştırma türleri arasında yer alan genel tarama yöntemlerinden tekil tarama yöntemleriyle geliştirilmiştir. $\mathrm{Bu}$ araştırmanın evrenini Ankara'da yaşamakta olan 16-27 yaş arası bireyler oluşturmaktadır. Örneklem çalışma grubu, Ankara ilinde ikamet eden 16-27 yaş arası bireylerden tamamen gönüllü olarak katılmaya rıza gösteren 218 'i kız $(\% 40,8)$ ve 150'i erkek $(\% 59,2)$ toplam 368 kişiden oluşmaktadır. $\mathrm{Bu}$ kişiler tamamen tesadüfi yöntemle seçilmiştir.

\subsection{Veri Toplama Araçları}

Araştırmanın çalışma grubu, Ankara ilinde ikamet eden 16-27 yaş arası gençlerden gönüllü olarak katılmaya rıza gösteren 218 'i kız $(\% 40,8)$ ve 150'i erkek $(\% 59,2)$ toplam 368 kişiden oluşmaktadır. Literatür irdelendiğinde, değişkenli tahlillerin yapılabilmesi maksadıyla ulaşılması gereken örneklem dozu hususunda başka ölçütler ve yargılar bulunmaktadır. Tavşancıl (2002) göre örneklem oranı, değişken, yani madde sayısının en az beş katı, hatta 10 katı olmalıdır. Preacher ve MacCallum (2002) en az örneklem oranının yüz ile iki yüz elli arasında olması gerektiğini belirtmiştir. Farklı fikirler ise madde rakamına göre değişken olarak cevap vermektedir.. Bu makalemizde de örneklem oranı, değişken, yani madde sayısının yaklaşık on beş katıdır. $\mathrm{Bu}$ araştırma, Allen (2011) tarafindan geliştirilen Obezite Farkındalığ1 Ölçeğinin, Türkçeye ve Türk kültürüne ve gelenek yapısına uyarlanması ile geçerlik ve güvenirlik çalışmalarının yapılması hedeflenmektedir. OFÖ madde sayısı 23 iken, örneklem 300 öğrenciden oluşmuştur. Aynı zamanda araştırmanın çalışma grubunun belirlenmesinde güç analiz yöntemi kullanılarak \%95 güven aralı̆̆ında ve \%80 güç ile örneklem büyüklügü en az 197 kişi olarak belirlendi.

Ölçeğin geliştirildiği ve uygulanması, ABD ile medeniyet ve kültür farklllıklarından ötürü ölçek adaptasyon evresi özenle takip edilmesi önem arz eden bir kısım kademelerden oluşmaktadır. $\mathrm{Bu}$ kademelerden ilki ölçeğin Türkçeye çevrilme aşamasıdır. Ölçek İngilizce tercüme biriminde çalışan üç akademisyence Türkçeye çevrilmiş ve bundan sonra ölçek Türkçe biriminde çalışan üç akademisyen topluluğu ile ölçeğin 2 hali aralarındaki çelişkiler irdelenmiştir. Yine bu akademisyenlerin ortaya çıkan bu verileri Türkçe formlar üstünde münazara ederek gramer ve anlam gerekli tüm değişiklikler yapılmıştır. Tüm bu aşamalar neticesinde ölçek ABD versiyonundan Türkçeye başarılı şekilde evirilmiş ve form Türkiye'de anket ölçeği şeklinde uyarlanmıştır. Ölçek bireylerin obezite farkındalığı, beslenme alışkanlıkları, fiziksel aktivite hususundaki fikirlerini ve obezite eğitimin kişiler adına tesirini geliştirmek için oluşturulmuştur. Örneğin orijinal formu 23 madde ve üç alt boyuttan oluşan ölçeğin alt boyutlanı; 1) Obezite farkındalı̆̆1 (8 madde), 2) Beslenme alt boyutu (7 madde) ve 3) fiziksel aktivite alt boyutlarından (8 madde) oluşmaktadır.

\subsection{Verilerin Toplanması ve Analizi}

Veri toplama aracı 16-27 yaş arasında Ankara'da ikamet etmekte olan toplam 368 gönüllü birey tarafindan doldurulmuştur. Veriler SPSS güncel programında değerlendirilmek ve analiz edilmek üzere bilgisayar ortamına aktarılmıştır. Katılımcılar ile ilgili demografik bilgiler, katıldıklanı fiziksel aktiviteler, sağlıklı beslenme düzeyleri ve obezite farkındalık düzeyleri ile ilgili verilerin analizinde betimsel istatistik yöntemleri uygulanmıştır.

Çalışmada anlam çıkancı (kestirimsel) istatistikler gerçekleştirilmeden öncelikle veri setinin dağılım yapısı ve merkezi eğilim değerleri incelenmiştir. Dağılım yapısının normalliği için literatürde ölçüt değerler olarak kabul gören kurtosis (basıklık) ve skewness (çarpıklık) değerlerine yakın değerler alıp almayışı değerlendirilmiştir. Bu dağılımların "-1.5 ile +1.5” (Tabachnick ve Fidell, 2013) veya “-2 ile +2" (George ve Mallery, 2010) aralıkları arasında yer alması normal bir dağglıma ölçüt 
referans olarak kabul edilmiştir. Ayrıca alan yazında konuya ilişkin başka bir ölçüte göre "verilerin ortalama, mod ve medyan değerlerinin birbirine yakınlığının verilerin normal dağılım gösterdiği şeklinde yorumlanabileceği” görüşü normallik hipotezi olarak değerlendirilmiştir (Büyüköztürk, Köklü ve Çokluk Bökeoğlu, 2006).

\section{Bulgular}

Katılımcıların cinsiyet, meslek, aylık gelir durumu, bki indeksi, yaş durumu, eğitim düzeyi, boy ve kilo değerlerinin katılan kişiler değişkenlerine ait frekans ve yüzde tabloları da aşağıda verilmiştir.

Çizelge 1.1. Tanımlayıcı İstatistik Tabloları

\begin{tabular}{lcc}
\hline Cinsiyet & f & \% \\
\hline Erkek & 150 & 40,8 \\
Kadın & 218 & 59,2 \\
\hline Toplam & 368 & 100 \\
\hline
\end{tabular}

\begin{tabular}{lcc}
\hline Yaş aralı̆̆1 & f & \% \\
\hline $16-18$ & 26 & 7,1 \\
$19-21$ & 108 & 29,3 \\
$22-24$ & 74 & 20,1 \\
$25-27$ & 160 & 43,5 \\
\hline Toplam & 368 & 100 \\
\hline & & \\
\hline Meslek & f & \% \\
\hline Kamu Çalışanı & 73 & 19,8 \\
Özel Sektör & 78 & 21,2 \\
Serbest Çalışan & 23 & 6,3 \\
Öğrenci & 175 & 47,6 \\
Diğger & 19 & 5,2 \\
\hline Toplam & 368 & 100 \\
\hline
\end{tabular}

\begin{tabular}{lcc}
\hline Gelir Durumu & f & $\mathbf{\%}$ \\
\hline $0-1000$ TL & 174 & 47,3 \\
$1001-2500$ TL & 45 & 12,2 \\
$2501-4000$ TL & 53 & 14,4 \\
$4001-5500$ TL & 29 & 7,9 \\
5501 TL ve üzeri & 67 & 18,2 \\
\hline Toplam & 368 & 100 \\
\hline
\end{tabular}

\begin{tabular}{lcc}
\hline Beden Kitle İndeksi & $\mathbf{f}$ & $\mathbf{\%}$ \\
\hline$<18.5=$ Zaylf & 52 & 14,1 \\
18.5-24.9 aras1=Normal & 188 & 51,1 \\
25-29.9 aras1=Fazla Kilolu & 96 & 26,1 \\
30-34.9 aras1= 1. Derece Obez & 30 & 8,2 \\
35-39.9 = 2. Derece Obez & 2 & 0,5 \\
\hline Toplam & 368 & 100 \\
\hline
\end{tabular}

\begin{tabular}{lcc}
\hline Eğitim Durumu & f & \% \\
\hline İlköğretim & 8 & 2,17 \\
Ortaöğretim & 25 & 6,79 \\
Önlisans & 37 & 10,05 \\
Lisans & 244 & 66,3 \\
Yüksek Lisans & 54 & 14,67 \\
\hline Toplam & 368 & 100 \\
\hline
\end{tabular}


Acaroğlu, T., \& Çolakoğlu, T. (2020). Spor Politikasi olarak Gençlerin Sportif Aktivitelere Yönlendirilmesi, Sağlıklı Beslenme ve Obezite Farkındalığ1. Journal of Human Sciences, 17(1), 340-358. doi:10.14687/jhs.v17i1.5944

Çizelge 1.1. e göre Cinsiyet değişkenine İlişkin Frekans ve Yüzde Tablosu yer alan betimsel veriler doğrultusunda araştırmaya gönüllü katılan 368 kişiden 150’sinin (\%46,8) erkek, 218’inin $(\% 53,2)$ ise kadın olduğu görülmüştür.

Yaş Değişkenine İlişkin Frekans ve Yüzde Tablosu, yaş değişkenine ilişkin yer verilen betimsel verilere göre araştırmaya katulan 368 kişiden 26’sının (\%7,1) 16-18 yaş, 108’inin (\%29,3) 19-21 yaş, 74'ünün (\%20,1) 22-24 yaş, 160’ ının (\%43,5) 25-27 yaşında yer aldığ1 görülmüștür.

Meslek Değişkenine İlişkin Frekans ve Yüzde Tablosu, meslek değişkenine ilişkin yer verilen betimsel verilere göre araştırmaya katılan 368 kişiden 73'ünün $(\% 19,8)$ kamu çalışanı, 78'inin $(\% 21,2)$ özel sektör, 23’ünün $(\% 6,3)$ serbest çalışan, 175 ininin $(\% 47,6)$ öğrenci ve geriye kalan 19 'unun $(\% 5,2)$ ise diğer kategorisinde yer aldığı görülmüştür.

Gelir Durumu Değişkenine İlişkin Frekans ve Yüzde Tablosu, gelir durumu değişkenine ilişkin yer verilen betimsel verilere göre araştırmaya katılan 368 kişiden 174'ünün (\%47,3) 0-1000 TL, 45’inin (\%12,2) 1001-2500 TL, 53'ünün (\%14,4) 2501-4000 TL, 29’unun (\%7,9) 4001-5500 TL ve geriye kalan 67'sinin $(\% 18,2)$ ise 5501 TL ve üzeri gelir aralığında yer aldığ1 görülmüştür.

Beden Kitle İndeksi Kategorisine İlişkin Frekans ve Yüzde Tablosu, beden kitle indeksi kategorisine ilişkin yer verilen betimsel verilere göre araştırmaya katılan 368 kişiden 52'sinin (\%14,1) zayıf, 188'inin $(\% 51,1)$ normal, 96 'sinin $(\% 26,1)$ fazla kilolu, 30'unun $(\% 8,2) 1$. Derece obez ve geriye kalan 2'sinin $(\% 0,5)$ ise 2 . Derece obez kategorisinde yer aldığ1 görülmüştür.

Eğitim Durumu Değişkenine İlişkin Frekans ve Yüzde Tablosu ,eğitim seviyesi değişkenine ilişskin olarak yer verilen betimsel verilere göre araşturmaya katılan 368 kişiden $8^{\prime}$ inin $(\% 7,1)$ ilköğretim, 25'inin (\%6,79) ortaöğretim, 37'sinin (\%10,05) ön lisans, 244'ünün (\%66,3) lisans ve geriye kalan 54’ünün $(\% 14,67)$ ise yüksek lisans mezunu olarak çalışmada yer aldığı görülmüştür.

Çizelge 1.2. Cinsiyet değişkenine göre Obezite farkındalık ölçeğinin bağımsız örneklem t-testi sonuçları

\begin{tabular}{|c|c|c|c|c|c|c|c|}
\hline Alt Boyutlar & Cinsiyet & $\mathrm{n}$ & $\overline{\mathbf{x}}$ & $\mathrm{S}$ & Sd & $t$ & $\mathrm{p}$ \\
\hline \multirow{2}{*}{ 1. Obezite Farkındalık } & Erkek & 150 & 3,00 & ,304 & \multirow{2}{*}{366} & \multirow{2}{*}{$-3,055$} & \multirow{2}{*}{.00} \\
\hline & Kadın & 218 & 3,10 & ,304 & & & \\
\hline \multirow{2}{*}{ 2. Beslenme } & Erkek & 150 & 3,13 & ,355 & \multirow{2}{*}{366} & \multirow{2}{*}{,- 947} & \multirow{2}{*}{.34} \\
\hline & Kadın & 218 & 3,17 &, 377 & & & \\
\hline \multirow{2}{*}{ 3.Fiziksel Aktivite } & Erkek & 150 & 2,84 & ,398 & \multirow{2}{*}{366} & \multirow{2}{*}{,- 675} & \multirow{2}{*}{.50} \\
\hline & Kadın & 218 & 2,87 & ,393 & & & \\
\hline \multirow{2}{*}{ 4. Ölçek Geneli } & Erkek & 150 & 3,00 & 273 & \multirow{2}{*}{366} & \multirow{2}{*}{$-2,141$} & \multirow{2}{*}{.03} \\
\hline & Kadın & 218 & 3,06 & ,277 & & & \\
\hline
\end{tabular}

Çizelge 1.2. 'da cinsiyete göre obezite farkındalık ölçeğinden elde edilen puanların gruplar arasında istatistiksel açıdan anlamlı bir farklılığa işaret edip etmediği değerlendirilmiştir. T-testi sonuçlarına göre obezite farkındalık alt boyutu $\left(\mathrm{t}_{(360)}=-3.055, \mathrm{p}<, 05\right)$ ve Obezite farkındalık ölçeği genelinde $\left(\mathrm{t}_{(360)}=-2.141, \mathrm{p}<, 05\right)$ gruplar arasında gerçekleşen ortalamaların istatistiksel açıdan anlamlı farklılıklar oluşturduğu ve bu durumun kadın katulımcılar lehine gerçekleştiği görülmüştür. Bununla birlikte obezite farkındalık ölçeğinin beslenme $\left(\mathrm{t}_{(366)}=-.947 \mathrm{p}>, 05\right)$ ve fiziksel aktivite $\left(\mathrm{t}_{(366)}=-.675\right.$, $\mathrm{p}>, 05)$ alt boyutlarında cinsiyete göre istatistiksel açıdan anlamlı bir farklılık bulunmadığ1 görülmüştür.

Çizelge 1.3. Yaş değişkenine göre Obezite farkındalık ölçeğinin tek yönlü varyans analizi sonuçları

\begin{tabular}{|c|c|c|c|c|c|c|c|}
\hline Alt Boyutlar & Yaş Değişkeni & $\mathrm{n}$ & $\overline{\mathbf{x}}$ & $\mathbf{S}$ & Sd & $f$ & $\mathrm{p}$ \\
\hline \multirow{4}{*}{ 1. Obezite Farkındalık } & $16-18$ & 26 & 3,05 & 206 & \multirow{4}{*}{$\begin{array}{c}4 \\
363 \\
367\end{array}$} & \multirow[t]{4}{*}{,328 } & \multirow[t]{4}{*}{.86} \\
\hline & $19-21$ & 108 & 3,05 & ,289 & & & \\
\hline & $22-24$ & 74 & 3,05 & ,322 & & & \\
\hline & $25-27$ & 160 & 3,11 & ,325 & & & \\
\hline
\end{tabular}


Acaroğlu, T., \& Çolakoğlu, T. (2020). Spor Politikasi olarak Gençlerin Sportif Aktivitelere Yönlendirilmesi, Sağlıklı Beslenme ve Obezite Farkındalığ1. Journal of Human Sciences, 17(1), 340-358. doi:10.14687/jhs.v17i1.5944

\begin{tabular}{|c|c|c|c|c|c|c|c|}
\hline \multirow{4}{*}{ 2. Beslenme } & $16-18$ & 26 & 3,02 &, 366 & \multirow{4}{*}{$\begin{array}{c}4 \\
363 \\
367\end{array}$} & \multirow[t]{4}{*}{1,524} & \multirow[t]{4}{*}{.19} \\
\hline & $19-21$ & 108 & 3,16 & ,361 & & & \\
\hline & $22-24$ & 74 & 3,11 & ,398 & & & \\
\hline & $25-27$ & 160 & 3,16 & ,387 & & & \\
\hline \multirow{4}{*}{ 3. Fiziksel Aktivite } & $16-18$ & 26 & 2,83 &, 411 & \multirow{4}{*}{$\begin{array}{c}4 \\
363 \\
367\end{array}$} & \multirow[t]{4}{*}{, 349} & \multirow[t]{4}{*}{.84} \\
\hline & $19-21$ & 108 & 2,87 &, 372 & & & \\
\hline & $22-24$ & 74 & 2,82 &, 416 & & & \\
\hline & $25-27$ & 160 & 2,83 & ,441 & & & \\
\hline \multirow{4}{*}{ 4. Toplam } & $16-18$ & 26 & 2,98 & 231 & \multirow{4}{*}{$\begin{array}{c}4 \\
363 \\
367\end{array}$} & \multirow[t]{4}{*}{, 512} & \multirow[t]{4}{*}{.73} \\
\hline & $19-21$ & 108 & 3,04 & ,261 & & & \\
\hline & $22-24$ & 74 & 3,01 &, 312 & & & \\
\hline & $25-27$ & 160 & 3,06 & 299 & & & \\
\hline
\end{tabular}

Çizelge 1.3.'de katılımcı bireylerin yaş değişkenine binaen tek yönlü varyans analizi sonuçları incelendiğinde, 16-18 yaş arasındaki gençlerin alt boyutlardaki toplam ömo değeri $\overline{\mathrm{X}}=2.98,19-21$ yaş arasındaki gençlerin toplam ömo değeri $\overline{\mathrm{X}}=3.04,22-24$ yaşları arasındaki gençlerin alt boyutlardaki toplam ömo değeri $\overline{\mathrm{X}}=3.01,25-27$ yaşları arasındaki gençlerin toplam ömo değeri $\overline{\mathrm{X}}=3,06$, olduğu görülmektedir. Katılımcı gençlerin yaşlarına göre sosyal alt boyutundan aldıkları puanlar arasında istatistiksel olarak $(\mathrm{p}<0,05)$ anlamlı düzeyde fark yoktur. Çizelge 7'de katıllimc1 bireylerin yaş değişkenine binaen tek yönlü varyans analizi sonuçları incelendiğinde obezite farkındalık $\left(F_{(4-367)}=0.328, p>.05\right)$, beslenme $\left(F_{(4-367)}=1.524, p>.05\right)$, fiziksel aktivite alt boyutlarında $\left(F_{(4-367)}=0.349, p>.05\right)$ ve ölçek genelinde $\left(F_{(4-367)}=1.291, p>.05\right)$ istatistiksel açıdan anlamlı bir farklllık göstermediği tespit edilmiştir.

Çizelge 1.4. Meslek kategorilerine göre Obezite farkındalık ölçeğinin tek yönlü varyans analizi sonuçları

\begin{tabular}{|c|c|c|c|c|c|c|c|c|}
\hline Alt Boyutlar & Meslek Kategorileri & $\mathbf{n}$ & $\overline{\mathbf{x}}$ & $\mathbf{S}$ & Sd & $\mathrm{f}$ & $\mathrm{p}$ & $\begin{array}{c}\text { Farkın } \\
\text { kaynağ1 }\end{array}$ \\
\hline \multirow{5}{*}{ 1. Obezite Farkındalık } & Kamu Çalışanı & 73 & 3,11 & ,320 & \multirow{5}{*}{$\begin{array}{c}4 \\
363 \\
367\end{array}$} & \multirow[t]{5}{*}{1,507} & \multirow[t]{5}{*}{.20} & \\
\hline & Özel Sektör & 78 & 3,04 & ,326 & & & & \\
\hline & Serbest Çalışan & 23 & 2,93 & ,314 & & & & \\
\hline & Öğrenci & 175 & 3,06 & 268 & & & & \\
\hline & Diğer & 19 & 3,04 & 466 & & & & \\
\hline \multirow{5}{*}{ 2. Beslenme } & Kamu Çalışanı $^{1}$ & 73 & 3,27 & ,343 & \multirow{5}{*}{$\begin{array}{c}4 \\
363 \\
367\end{array}$} & \multirow[t]{5}{*}{2,841} & \multirow[t]{5}{*}{.02} & \multirow[t]{5}{*}{$1>4$} \\
\hline & Özel Sektör ${ }^{2}$ & 78 & 3,15 & ,338 & & & & \\
\hline & Serbest Çalışan ${ }^{3}$ & 23 & 3,09 & ,317 & & & & \\
\hline & Öğrenci 4 & 175 & 3,12 &, 376 & & & & \\
\hline & Diğer ${ }^{5}$ & 19 & 3,05 & ,484 & & & & \\
\hline \multirow{5}{*}{ 3. Fiziksel Aktivite } & Kamu Çalışanı & 73 & 2,90 & ,427 & \multirow{5}{*}{$\begin{array}{c}4 \\
363 \\
367\end{array}$} & \multirow[t]{5}{*}{0,945} & \multirow[t]{5}{*}{.44} & \\
\hline & Özel Sektör & 78 & 2,88 &, 427 & & & & \\
\hline & Serbest Çalışan & 23 & 2,91 &, 324 & & & & \\
\hline & Öğrenci & 175 & 2,81 &, 372 & & & & \\
\hline & Diğer & 19 & 2,88 & 413 & & & & \\
\hline \multirow{5}{*}{ 4. Ölçek Genelinde } & Kamu Çalışanı & 73 & 3,11 & 272 & \multirow{5}{*}{$\begin{array}{c}4 \\
363 \\
367\end{array}$} & \multirow[t]{5}{*}{1,699} & \multirow[t]{5}{*}{.15} & \\
\hline & Özel Sektör & 78 & 3,03 & 283 & & & & \\
\hline & Serbest Çalışan & 23 & 2,98 & 254 & & & & \\
\hline & Öğrenci & 175 & 3,02 & 259 & & & & \\
\hline & Diğer & 19 & 3,00 & ,408 & & & & \\
\hline
\end{tabular}


Çizelge 1.4.'de katllımcıların meslek kategorilerine göre tek yönlü varyans analizi sonuçları incelendiğinde obezite farkındalık $\left(F_{(4-367)}=1.507, p>.05\right)$, fiziksel aktivite alt boyutlarında $\left(F_{(4-367)}=\right.$ $0.945, p>.05)$ ve ölçek genelinde $\left(F_{(4-367}=1.699, p>.05\right)$ istatistiksel açıdan anlamlı bir farklılık göstermediği tespit edilmiştir. Bununla birlikte beslenme alt boyutunda meslek kategorilerine göre grup ortalamaları arasında istatistiksel açından anlamlı bir farklılık bulunduğu görülmüştür. Anlamlı farkı tespit etmek üzere gerçekleştirilen Tukey testi sonuçları incelendiğinde farkın kamu çalışanları $\left(X_{1}=3,27\right)$ ile öğrenciler $\left(X_{4}=3,12\right)$ arasında ve kamu çalışanları lehine gerçekleştiği görülmüştür $\left(F_{(4-367)}=2.841, p<.05\right)$.

Çizelge 1.5. Eğitim seviyesine göre obezite farklllığı boyutuna ilişkin Kruskal Wallis H testi

\begin{tabular}{lcccc}
\hline Eğitim Seviyesi & $\mathbf{n}$ & $\begin{array}{c}\text { S1ra } \\
\text { Ortalaması }\end{array}$ & $\mathbf{X}^{2}$ & $\mathbf{p}$ \\
\hline \hline İlköğretim & 8 & 185 & 6,936 & .14 \\
Lise & 25 & 141 & & \\
Önlisans & 37 & 189 & & \\
Lisans & 244 & 183 & & \\
Yüksek Lisans & 54 & 208 & & \\
Total & 368 & & & \\
\hline \hline
\end{tabular}

Katılımcıların obezite farkındalığının eğitim seviyesine göre farklılaşıp farklılaşmadığını belirlemek üzere gerçekleştirilen Kruskal Wallis $H$ testi sonuçları tablo 6.10.'de verilmiştir. Tablodaki sonuçlara göre katılımcıların obezite farkındalık alt boyutundan elde edilen puanların eğitim seviyesi değişkeni bakımından anlamlı bir farklılık göstermediği görülmüştür $\left(\mathrm{x}^{2}=6,936\right.$; $\mathrm{p}>, 05)$.

Çizelge 1.6. Gelir değişkenine göre Obezite farkındalık ölçeğinin tek yönlü varyans analizi sonuçları

\begin{tabular}{|c|c|c|c|c|c|c|c|c|}
\hline Alt Boyutlar & Gelir Durumu & $\mathbf{n}$ & $\overline{\mathbf{x}}$ & $\mathbf{S}$ & Sd & $\mathbf{F}$ & $\mathrm{p}$ & $\begin{array}{l}\text { Farkın } \\
\text { kaynağı }\end{array}$ \\
\hline \multirow{5}{*}{ 1. Obezite Farkındalık } & $0-1000 \mathrm{TL}^{1}$ & 174 & 3,06 & ,300 & \multirow{5}{*}{$\begin{array}{c}4 \\
363 \\
367\end{array}$} & \multirow[t]{5}{*}{2,648} & \multirow[t]{5}{*}{.03} & $5>3$ \\
\hline & $1001-2500 \mathrm{TL}^{2}$ & 45 & 3,09 & ,321 & & & & \multirow[t]{4}{*}{$5>4$} \\
\hline & $2501-4000 \mathrm{TL}^{3}$ & 53 & 2,98 &, 325 & & & & \\
\hline & $4001-5500 \mathrm{TL}^{4}$ & 29 & 2,97 & ,294 & & & & \\
\hline & 5501 TL ve üzeri ${ }^{5}$ & 67 & 3,13 & ,294 & & & & \\
\hline \multirow{5}{*}{ 2. Beslenme } & $0-1000 \mathrm{TL}$ & 174 & 3,13 & ,393 & \multirow{5}{*}{$\begin{array}{c}4 \\
363 \\
367\end{array}$} & \multirow[t]{5}{*}{1,200} & \multirow[t]{5}{*}{.31} & \\
\hline & $1001-2500 \mathrm{TL}$ & 45 & 3,17 & 361 & & & & \\
\hline & $2501-4000 \mathrm{TL}$ & 53 & 3,10 & ,354 & & & & \\
\hline & $4001-5500 \mathrm{TL}$ & 29 & 3,13 &, 290 & & & & \\
\hline & 5501 TL ve üzeri & 67 & 3,23 & ,344 & & & & \\
\hline \multirow{5}{*}{ 3. Fiziksel Aktivite } & $0-1000 \mathrm{TL}$ & 174 & 2,83 &, 401 & \multirow{5}{*}{$\begin{array}{c}4 \\
363 \\
367\end{array}$} & \multirow[t]{5}{*}{1,303} & \multirow[t]{5}{*}{.27} & \\
\hline & $1001-2500 \mathrm{TL}$ & 45 & 2,94 & ,498 & & & & \\
\hline & 2501-4000 TL & 53 & 2,91 & ,298 & & & & \\
\hline & $4001-5500 \mathrm{TL}$ & 29 & 2,90 & 341 & & & & \\
\hline & 5501 TL ve üzeri & 67 & 2,80 & ,384 & & & & \\
\hline \multirow{5}{*}{ 4. Toplam } & 0-1000 TL & 174 & 3,02 &, 293 & \multirow{5}{*}{$\begin{array}{c}4 \\
363 \\
367\end{array}$} & \multirow[t]{5}{*}{1,151} & \multirow[t]{5}{*}{.33} & \\
\hline & $1001-2500 \mathrm{TL}$ & 45 & 3,08 &, 314 & & & & \\
\hline & $2501-4000 \mathrm{TL}$ & 53 & 3,00 &, 246 & & & & \\
\hline & $4001-5500 \mathrm{TL}$ & 29 & 3,00 &, 236 & & & & \\
\hline & 5501 TL ve üzeri & 67 & 3,08 &, 242 & & & & \\
\hline
\end{tabular}


Çizelge 1.6.'de gelir kategorilerine göre tek yönlü varyans analizi sonuçları incelendiğinde obezite farkındalık boyutunda meslek kategorilerine göre grup ortalamaları arasında istatistiksel açından anlamlı bir farkllık bulunduğu görülmüştür. Anlamlı farkı tespit etmek üzere gerçekleştirilen Tukey testi sonuçları incelendiğinde farkın "5501TL ve üzeri" $\left(\bar{X}_{5}=3,13\right)$ gelir grubunda yer alan katilimcilarla sirasiyla; "2501-4000 TL" $\left(\bar{X}_{3}=3,98\right)$ grubu ve "4001-5500 TL" grubu $\left(\bar{X}_{3}=3,98\right)$ arasında ve "5501TL ve üzeri” gelir grubu lehine gerçekleștiği görülmüştür $\left(F_{(4-367)}=2.648, p<.05\right)$. Beslenme $\left(F_{(4-367)}=1.200, p>.05\right)$ ve fiziksel aktivite $\left(F_{(4-367)}=1.303, p>.05\right)$ alt boyutları ile ölçek genelinde ise $\left(F_{(4-367)}=1.699, p>.05\right)$ gelir kategorileri açısından anlamlı bir farklılık görülmemiştir.

Çizelge 1.7. Eğitim seviyesine göre Beslenme boyutuna ilişkin Kruskal Wallis H testi sonuçları

\begin{tabular}{lccccc}
\hline Eğitim Seviyesi & $\mathbf{n}$ & $\begin{array}{c}\text { S1ra } \\
\text { Ortalamas1 }\end{array}$ & $\mathbf{X}^{\mathbf{2}}$ & $\mathbf{p}$ & Fark \\
\hline \hline İlköğretim & 8 & 190 & 1,168 & .88 & \\
Lise & 25 & 170 & & & \\
Önlisans & 37 & 181 & & & \\
Lisans & 244 & 184 & & & \\
Yüksek Lisans & 54 & 196 & & & \\
Total & 368 & & & & \\
\hline \hline
\end{tabular}

Katılımcıların beslenme boyutundan elde edilen puanların eğitim seviyesi değişkeni bakımından farklılaşıp farklılaşmadığını belirlemek üzere gerçekleştirilen Kruskal Wallis H testi sonuçları çizelge 6.12.'de verilmiştir. Tablodaki sonuçlara göre katilımcıların beslenme alt boyutundan elde edilen puanların eğitim seviyesi değişkeni bakımından anlamlı bir farklılık göstermediği görülmüştür $\left(x^{2}=1,168 ; p>, 05\right)$.

Çizelge 1.8. Eğitim seviyesine göre fiziksel aktivite boyutuna ilişkin Kruskal Wallis H testi sonuçları

\begin{tabular}{lcccc}
\hline \hline Eğitim Seviyesi & $\mathbf{n}$ & $\begin{array}{c}\text { Sira } \\
\text { Ortalamasi }\end{array}$ & $\mathbf{X}^{\mathbf{2}}$ & $\mathbf{p}$ \\
\hline \hline İlköğretim & 8 & 221 & 5,237 & .26 \\
Lise & 25 & 201 & & \\
Önlisans & 37 & 213 & & \\
Lisans & 244 & 178 & & \\
Yüksek Lisans & 54 & 183 & & \\
Total & 368 & & & \\
\hline \hline
\end{tabular}

Katılımcıların fiziksel aktivite boyutundan elde edilen puanların eğitim seviyesi değişkeni bakımından farklılaşıp farklılaşmadığını belirlemek üzere gerçekleştirilen Kruskal Wallis $\mathrm{H}$ testi sonuçları çizelge 6.10.'te verilmiştir. Tablodaki sonuçlara göre katılımcıların fiziksel aktivite alt boyutundan elde edilen puanların eğitim seviyesi değişkeni bakımından anlamlı bir farklılık göstermediği görülmüştür $\left(\mathrm{x}^{2}=5,237 ; \mathrm{p}>, 05\right)$. 
Acaroğlu, T., \& Çolakoğlu, T. (2020). Spor Politikasi olarak Gençlerin Sportif Aktivitelere Yönlendirilmesi, Sağlıklı Beslenme ve Obezite Farkındalığ1. Journal of Human Sciences, 17(1), 340-358. doi:10.14687/jhs.v17i1.5944

Çizelge 1.9. Eğitim seviyesine göre obezite farklılı̆̆ı ölçeği genelinden elde edilen puanların Krsukal Wallis $\mathrm{H}$ testi sonuçları

\begin{tabular}{lcccc}
\hline \hline Eğgitim Seviyesi & $\mathbf{n}$ & $\begin{array}{c}\text { Sira } \\
\text { Ortalamasi }\end{array}$ & $\mathbf{X}^{\mathbf{2}}$ & $\mathbf{p}$ \\
\hline \hline İlköğretim & 8 & 201 & 3,829 & .43 \\
Lise & 25 & 159 & & \\
Önlisans & 37 & 194 & \\
Lisans & 244 & 181 & \\
Yüksek Lisans & 54 & 203 & \\
Total & 368 & & \\
\hline \hline
\end{tabular}

Katılımcıların obezite farkındalığı ölçeği genelinde elde edilen toplam puanlarının eğitim seviyesi değişkeni bakımından farklılaşıp farklılaşmadığını belirlemek üzere gerçekleştirilen Kruskal Wallis H testi sonuçları Çizelge 15.'te verilmiştir. Tablodaki sonuçlara göre katıllımcıların obezite farkındalık ölçeğinden elde edilen puanların eğitim seviyesi bakımından anlamlı bir farklılık göstermediği görülmüştür $\left(x^{2}=3,829 ; \mathrm{p}>, 05\right)$.

Çizelge 1.10. BKİ kategorilerine göre Obezite farkındalık ölçeğinin tek yönlü varyans analizi sonuçları

\begin{tabular}{|c|c|c|c|c|c|c|c|}
\hline Alt Boyutlar & BKİ Kategorileri & $\mathbf{n}$ & $\overline{\mathbf{x}}$ & $\mathbf{S}$ & Sd & $\mathbf{f}$ & p \\
\hline \multirow{4}{*}{ 1. Obezite Farkındalık } & $<18.5=$ Zayif & 52 & 3,05 &, 307 & \multirow{4}{*}{$\begin{array}{c}4 \\
363 \\
367\end{array}$} & \multirow[t]{4}{*}{1,112} & \multirow[t]{4}{*}{.34} \\
\hline & 18.5-24.9 aras1 $=$ Normal & 188 & 3,07 &, 301 & & & \\
\hline & 25-29.9 arası=Fazla Kilolu & 96 & 3,01 &, 325 & & & \\
\hline & 30-34.9 arası $=1$. Derece Obez & 32 & 3,11 & ,293 & & & \\
\hline \multirow{4}{*}{ 2. Beslenme } & $<18.5=$ Zayıf & 52 & 3,15 &, 361 & \multirow{4}{*}{$\begin{array}{c}4 \\
363 \\
367\end{array}$} & \multirow[t]{4}{*}{, 674} & \multirow[t]{4}{*}{.5} \\
\hline & $18.5-24.9$ aras $1=$ Normal & 188 & 3,17 &, 375 & & & \\
\hline & 25-29.9 arası=Fazla Kilolu & 96 & 3,13 &, 347 & & & \\
\hline & $30-34.9$ aras $1=1$. Derece Obez & 32 & 3,08 & ,404 & & & \\
\hline \multirow{4}{*}{ 3. Fiziksel Aktivite } & $<18.5=$ Zayılf & 52 & 2,85 &, 390 & \multirow{4}{*}{$\begin{array}{c}4 \\
363 \\
367\end{array}$} & \multirow[t]{4}{*}{1,086} & \multirow[t]{4}{*}{.35} \\
\hline & 18.5-24.9 aras $1=$ Normal & 188 & 2,88 &, 410 & & & \\
\hline & 25-29.9 arası=Fazla Kilolu & 96 & 2,84 &, 367 & & & \\
\hline & $30-34.9$ arası $=1$. Derece Obez & 32 & 2,75 &, 387 & & & \\
\hline \multirow{4}{*}{ 4. Toplam } & $<18.5=$ Zayılf & 52 & 3,03 &, 284 & \multirow{4}{*}{$\begin{array}{c}4 \\
363 \\
367\end{array}$} & \multirow[t]{4}{*}{,717 } & \multirow[t]{4}{*}{.54} \\
\hline & 18.5-24.9 aras $1=$ Normal & 188 & 3,05 &, 269 & & & \\
\hline & 25-29.9 arası=Fazla Kilolu & 96 & 3,01 &, 284 & & & \\
\hline & $30-34.9$ aras1 $=1$. Derece Obez & 32 & 3,01 &, 292 & & & \\
\hline
\end{tabular}

Çizelge 1.10'da katılımcıların “Beden Kitle İndeksi” kategorilerine göre gerçekleştirilen tek yönlü varyans analizi sonuçlanı incelendiğinde; obezite farkındalı $\left(F_{(4-367)}=1.112, p>.05\right)$, beslenme $\left(F_{(4-367)}=0.674, p>.05\right)$, fiziksel aktivite alt boyutlarında $\left(F_{(4-367)}=1.086, p>.05\right)$ ve ölçek genelinde $\left(F_{(4-367)}=0.717, p>.05\right)$ istatistiksel açıdan anlamlı bir farklılık göstermediği tespit edilmiştir. 
Acaroğlu, T., \& Çolakoğlu, T. (2020). Spor Politikasi olarak Gençlerin Sportif Aktivitelere Yönlendirilmesi, Sağlıklı Beslenme ve Obezite Farkındalığ1. Journal of Human Sciences, 17(1), 340-358. doi:10.14687/jhs.v17i1.5944

\section{Sonuç, Tartışma ve Öneriler}

Araştırma Ankara genelinde 16-27 yaş arasındaki gençlerin obezite farkındalık düzeyleri, beslenme davranışı ve fiziksel aktivite düzeylerini belirlemek ve bunun sonucunda makul ve tutarlı spor politikaları geliştirilmesine katkı sağlamak maksadıyla yapılmış olup sonuçlar aşağıdadır.

Fiziksel aktivite düzeyleri ile obezite farkındalık düzeyleri arasında pozitif yönde anlamlı düzeyde bir ilişki; fiziksel aktivite düzeyleri ile obezite farkındalığı, fiziksel aktivite düzeyi ile beslenme farkındalığı, fiziksel aktivite düzeyi ile fiziksel aktivite farkındalığı boyutları arasında da yine aynı şekilde pozitif yönde manalı seviyede bir bağ olduğu görülmektedir.

Cinsiyete göre obezite farkındalık ölçeğinden elde edilen puanların gruplar arasında istatistiksel açıdan anlamlı bir farklılığa işaret edip etmediği değerlendirilmiştir. T-testi sonuçlanına göre obezite farkındalık alt boyutu gruplar arasında gerçekleşen ortalamaların istatistiksel açıdan anlamlı farklılıklar oluşturduğu ve bu durumun kadın katılımcılar lehine gerçekleştiği görülmüştür. Kadınların obezite konusunda daha bilinçli olduğu tespit edilmiştir. Bununla birlikte obezite farkındalık, ölçeğinin beslenme ve fiziksel aktivite alt boyutlarında cinsiyete göre istatistiksel açıdan anlamlı bir farklılık bulunmadığı görülmüştür.

Katılımcıların yaş değişkenine göre tek yönlü varyans analizi sonuçları incelendiğinde, Katılımc1 gençlerin yaşlarına göre sosyal alt boyutundan aldıkları puanlar açısından istatistiksel olarak anlamlı düzeyde fark yoktur. Çizelge 7'de katılımcıların katılımcı bireylerin yaş değişkenine binaen tek yönlü varyans analizi sonuçları incelendiğinde obezite farkındalık, beslenme, fiziksel aktivite alt boyutlarında ve ölçek genelinde istatistiksel bakımdan manalı bir farklılık göstermediği tespit edilmiştir.

Katılımcıların meslek durumlarına bakıldığında ise meslek değişkenine ilişkin yer verilen betimsel verilere göre araşturmaya katılan 368 kişiden 73'ünün $(\% 19,8)$ kamu çalışanı, 78’inin $(\% 21,2)$ özel sektör, 23’ünün $(\% 6,3)$ serbest çalışan, 175'inin $(\% 47,6)$ öğrenci ve geriye kalan 19 'unun $(\% 5,2)$ ise diğer kategorisinde yer aldığı görülmüştür. Bununla alakalı olarak yapılan analiz sonucuna göre ise katulımcıların meslek kategorilerine göre tek yönlü varyans analizi sonuçları incelendiğinde obezite farkındalık, fiziksel aktivite alt boyutlarında ve ölçek genelinde istatistiksel bakımdan anlamlı bir farkllık göstermediği tespit edilmiştir. Bununla birlikte beslenme alt boyutunda meslek kategorilerine göre grup ortalamaları arasında istatistiksel açından manalı bir farklılık bulunduğu görülmüştür. Anlamlı farkı tespit etmek üzere gerçekleştirilen Tukey testi sonuçları incelendiğinde farkın kamu çalışanları $\left(\bar{X}_{1}=3,27\right)$ ile öğrenciler $\left(\bar{X}_{4}=3,12\right)$ arasında ve kamu çalışanları lehine gerçekleştiği görülmüştür.

Katulımcıların Aylık kazanç durumlarına göre yapılan analize göre ise gelir durumu değişkenine ilişkin yer verilen betimsel verilere göre araştırmaya katılan 368 kişiden 174'ünün (\%47,3) 0-1000 TL, 45’inin (\%12,2) 1001-2500 TL, 53'ünün (\%14,4) 2501-4000 TL, 29’unun (\%7,9) 4001-5500 TL ve geriye kalan 67'sinin $(\% 18,2)$ ise 5501 TL ve üzeri gelir aralığında yer aldığı görülmüştür.

Gelir kategorilerine göre tek yönlü varyans analizi sonuçları incelendiğinde obezite farkındalık boyutunda meslek kategorilerine göre grup ortalamaları arasında istatistiksel açından anlamlı bir farklılık bulunduğu görülmüştür. Anlamlı farkı tespit etmek üzere gerçekleştirilen Tukey testi sonuçları incelendiğinde farkın "5501TL ve üzeri" $\left(\bar{X}_{5}=3,13\right)$ gelir grubunda yer alan katıllımcılarla sirasiyla; "2501-4000 TL" $\left(\bar{X}_{3}=3,98\right)$ grubu ve "4001-5500 TL" grubu $\left(\bar{X}_{3}=3,98\right)$ arasinda ve "5501TL ve üzeri”" gelir grubu lehine gerçekleştiği görülmüştür. Beslenme ve fiziksel aktivite alt boyutları ile ölçek genelinde ise gelir kategorileri açısından anlamlı bir farkllılk görülmemiştir.

Katılımcıların BKİ verilerine göre yapılan analize göre beden kitle indeksi kategorisine ilişkin yer verilen betimsel verilere göre araştırmaya katılan 368 kişiden 52'sinin (\%14,1) zayıf, 188 'inin $(\% 51,1)$ normal, 96'sinin $(\% 26,1)$ fazla kilolu, 30'unun $(\% 8,2) 1$. Derece obez ve geriye kalan 2 'sinin $(\% 0,5)$ ise 2. Derece obez kategorisinde yer aldığ1 görülmüştür.

Çizelge 11'da katılımcıların "Beden Kitle İndeksi” kategorilerine göre gerçekleştirilen tek yönlü varyans analizi sonuçları incelendiğinde; obezite farkındalık, beslenme, fiziksel aktivite alt boyutlarında ve ölçek genelinde istatistiksel açıdan anlamlı bir farklılık göstermediği tespit edilmiştir. 
Katılımcıların eğitim durumlarına göre yapılan analize göre ise eğitim seviyesi değişkenine ilişkin olarak yer verilen betimsel verilere göre araştırmaya katılan 368 kişiden 8'inin (\%7,1) ilköğretim, 25’inin $(\% 6,79)$ ortaöğretim, 37’sinin $(\% 10,05)$ önlisans, 244’ünün $(\% 66,3)$ lisans ve geriye kalan 54’ünün $(\% 14,67)$ ise yüksek lisans mezunu olarak çalışmada yer aldığ1 görülmüştür.

Katılımcıların obezite farkındalığının eğitim seviyesine göre farklılaşıp farklılaşmadığını belirlemek üzere gerçekleştirilen Kruskal Wallis $\mathrm{H}$ testi sonuçlarına göre katılımcıların obezite farkındalık alt boyutundan elde edilen puanların eğitim seviyesi değişkeni bakımından anlamlı bir farklılık göstermediği görülmüştür. Katılımcıların beslenme boyutundan elde edilen puanların eğitim seviyesi değişkeni bakımından farklılaşıp farklılaşmadığını belirlemek üzere gerçekleştirilen Kruskal Wallis $\mathrm{H}$ testi sonuçlarına göre katılımcıların beslenme alt boyutundan elde edilen puanların eğitim seviyesi değişkeni bakımından anlamlı bir farklılık göstermediği görülmüştür. Katılımcıların fiziksel aktivite boyutundan elde edilen puanların eğitim seviyesi değişkeni bakımından farklılaşıp farklılaşmadığını belirlemek üzere gerçekleştirilen Kruskal Wallis $H$ testi sonuçlarına göre katılımcıların fiziksel aktivite alt boyutundan elde edilen puanların eğitim seviyesi değişkeni bakımından anlamlı bir farklılık göstermediği görülmüştür. Katıllımcıların obezite farkındalı̆̆ı ölçeği genelinde elde edilen toplam puanlarının eğitim seviyesi değişkeni bakımından farklılaşıp farklılaşmadığını belirlemek üzere gerçekleştirilen Kruskal Wallis $\mathrm{H}$ testi sonuçlarına göre eğitim seviyesi bakımından anlamlı bir farklılık göstermediği görülmüştür.

Tüm bu yapılan çalışmalar neticesinde ortaya çıkan sonuçlardan bizim açımızdan en mühim olanı bunların derlenip toparlanarak bir spor politikası haline getirilmesidir. Dünya genelinde yapılan çalışmalarda ortaya çıktığı gibi gençlerin geneli beslenme konusunda bilinçsiz ve yetersiz durumdadır. Ayrıca büyük çoğunluğunun fiziksisel aktivite düzeyleri yok denecek kadar azdır. Obezite konusunda ise erkeklerin büyük çoğunluğu daha bilinçsizken mesleki olarak da kamu personeli dışındaki meslek gruplanı beslenme konusunda bilinçsiz, öğrenciler ise beslenme hususunda tahminen fast food tarzı beslenmeye kendini adamış durumda olduklarından sağlıklı ve dengeli beslenmeden uzak kalmaktadırlar. Tüm bu sonuçlar 1şı̆̆ında Gençlik ve Spor Bakanlığ1 bünyesinde gerekli arge çalışmaları yapılarak kapsamlı ve detaylı bir spor politikası ve buna benzer farklı projeler geliştirilmelidir. Bizim çalışmamızda ortaya çıkan sonuçlara göre erkeklere farkındalık programları uygulanabileceği gibi kadınlara da fiziksel aktivitelere karşı duyarlı olunmasını sağlayacak yeni projeler oluşturulması esastır. Bunun yanı sıra beslenme konusunda daha bilinçsiz olan gençler içinse üniversitelerde ve kyk yurtlarında 4 çeşit yemek yerine diyet menüler konulabilir, kyk yurtlarında şeker kullanımını azaltmak ve beyaz ekmek yerine tam buğday veya kepek ekmek tercih edilmesi de yine oluşturulan kapsamlı politikalara ek maddeler olarak eklenebilir.Gerekli Spor ve sağlık tesisleri kurulduktan sonra her Üniversite öğrencisinin BKİ değerleri tespit edilerek ihtiyac1 olduğu anlaşılan öğrencilere ücretsiz diyetisyen imkanı, kondisyon ve fiziksel aktivite programları yazilabilir.

Kamu personeli olan 16-27 yaş arası gençler içinse sürekli ve uzun süreli oturmalar hem motive düşüklüğü hemde iş gücü kaybına yol açtı̆̆ düşünülmektedir. Bununla alakalı olarak ise harekete geç sloganına emsal oluşturulabilecek bir slogan ile her çalışanın kendine has bir spor branşını seçmesi sağlanarak gerekli ortam ve imkânlar dâhilince belli bir düzen çerçevesinde buralarda egzersizlere yönlendirilebilirler. Bu sayede hem sağlık giderleri azalmış olacak hem de bireylerin mental olarak rahatlaması ile beraber kamu da kuşkusuz iş verimi artacaktır.

Bunlarla alakalı olarak yapılan çalışmalarda da görüldüğü üzere; Çalışanların benzer yaştaki çalışmayan kişilere nazaran sağlık durumları kıyas edildiğinde çalışan kişilerin fiziksel aktivite, beslenme düzeyleri ve alkol, sigara tiryakilik seviyeleri çalısmayan kişilere nazaran yüksek olduğu görülmüş̧ür. Çalışılan yerlerin etrafi; çalışanların, sağlıksız besin tercihi ya da tüketimi, obezite olma ve gereğinden az fiziksel aktivite düzeyleri ile yakından ilişkilidir ( French, Harnack, Toomey \& Hannan, 2007)

$\mathrm{Bu}$ sonuçlar 1şı̆̆ında eğitim düzenine ilişkin sporla alakalı farklı politikalar geliştirilmelidir: Hükümet sporu bir eğitim kolu olarak benimsemeli, buna haiz kaynaklar oluşturmalı ve gerekirse bütçe ayırmalı ve yapılacak spor tesislerin her yaştan ve meslekten vatandaşların spor yapmasına 
firsat vermesi sağlanmalıdır. Bunun için ilk olarak spor yönetimleri bünyesinde bir Spor Bilgi Merkezi kurulabilir ve bu merkez, taşra ile devamlı olarak doküman ve bilgi iletişimi içerisinde olabilir.

Sınırlı ekonomik kaynakların çoğaltılması sağlanmalıdır: Ekonomik kaynaklardan Spora tahsis edilen kaynakların yanlış ve politik amaçlarla kullanılmasının önüne geçilmelidir. Gönüllü ve özerk kuruluşlar sporun içine çekilmelidir

Elde edilen bu verilerle manidar ve makul spor politikaları geliştirilmesine katkı sağlamak istenirse gerekenler kısaca şöyle özetlenebilir. Gençlerin gün geçtikçe azalan fiziksel aktivitelerinin seviyesi artırılmalıdır. Kadınların fiziksel aktiviteye katılımı ve yönlendirilmesi sağlanmalıdır. Erkeklerin obezite konusunda yeterli düzeyde bilinçlendirilmesi sağlanmalıdır. Sağlıklı beslenme alışkanlığı kazandırılmalıdır. Fiziksel aktivitenin obezite faktörüne olan etkisi üzerinde gerekli bilgililer verilmelidir. Düzenli yapılan fiziksel aktivite beslenme şekli ile desteklenmelidir. Öncelikle gençler olmak üzere vatandaşlarımız sağlıklı bir birey olmanın beslenme ve aynı zamanda düzenli ve programlı yapılan egzersiz ile sağlanacağı konusunda bilgilendirilmelidir. Sadece boş zamanlarda değil günün belli saatlerinde net bir zaman aralığı ayrılarak fiziksel aktivitelere de zaman ayrılmalıdır. Sporla ilgili olarak tüm devlet kurumlarının ortak hareket edebileceği platformlar oluşturulmalıdır: Devlet bugün bir spor politikası yürüterek onun yaygınlaştırılmasını sağlarken, diğer taraftan bunu engelleyici uygulamalar yapmaktadır. Bunun bir örneği, Milli Eğitim Bakanlı̆̆ı'nın Beden Eğitimi ve Spor derslerinin akıbetidir. Bugün ilk ve orta dereceli okullarda, Beden Eğitimi ve Spor derslerine yeterince ilgi ve değer gösterilmediği de genel bir kabul halini almıştır. Bu durum, gençliğin spor bilinci kazanması yoluna konmuş bir taştır. Böylece umut ederiz ki fizik kondisyon seviyesi yüksek ve bu kondisyonun sağladığı mental rahatlığa ulaşarak, beslenme konusunda daha bilinçli ve sağliklı nesillere ulaşmak suretiyle gençliğimiz muasır seviyeye ulaşsın böylece oluşturulan politikaların neticesinde pozitif dönüşler de şüphesiz artacaktır.

\section{Kaynakça}

Allen, A. (2011) effects of educational intervetion on children's knowledge of obesity risk factors.

Phd thesis. Carroll College

Altay, M. ( 2007) Çocukluk ve Ergenlikteki Fiziksel Aktivite Deneyimleri ile Yetişkinlikteki Fiziksel Aktivite Düzeyi Arasındaki ilişki Doktora Tezi, Gazi Üniversitesi, Ankara.

Aydın, A.D., Demir, H., Yetim, A.A., (2007), Türk spor politikalarında öngörülen hedeflerin gerçekleşme düzeylerinin belirlenmesi üzerine bir araştırma (GSGM örneği), Niğde Üniversitesi Beden Eğitimi ve Spor Bilimleri Dergisi, 1, (2): 87-96.

Bilir, N., Yıldız, N. A.(2006). İş Sağlığı ve Güvenliği. Güler, Ç., Akın, İ. (Ed). Halk Sağlığı Temel Bilgiler, Hacettepe Üniversitesi Yayınlan, Ankara, 602-631

Büyüköztürk, Ş., Köklü, N. ve Çokluk-Bökeoğlu, Ö. (2006). Sosyal Bilimleri için İstatistik, 2. Baskı. Ankara.

Doğan, G., MendeG,, B., Akcan, F., Tepe, A. (2016). Futbolculara uygulanan sekiz haftalık core antrenmanın bazı fiziksel ve fizyolojik parametreler üzerine etkisi. Niğde Üniversitesi Beden Eg̈itimi ve Spor Bilimleri Dergisi, 10 (1), 2-10.

Fişek, K., (1980), Devlet politikası ve toplumsal yapıyla ilişkileri açısından spor yönetimi DünyadaTürkiye eede, Ankara Üniversitesi Siyasal Bilgiler Fakültesi Yayınları, Ankara.

French, A. S., Harnack, L. J., Toomey, L. T., Hannan, P. J. (2007). Association between body weight, physical activity and food choices among metropolitan transit workers. IJBNPA, 4:52.

George, D., \& Mallery, M. (2010). SPSS for Windows Step by Step: A Simple Guide and Reference, 17.0 update (10. ed.) Boston: Pearson.

Güler, Y., Gönener, H.D, Altay, B., Gönener, A. (2009). Adölesanlarda obezite ve hem Ģirelik bakımı. Firat Sağlık Hizmetleri Dergisi. 4 (10): 165- 181. 
Acaroğlu, T., \& Çolakoğlu, T. (2020). Spor Politikasi olarak Gençlerin Sportif Aktivitelere Yönlendirilmesi, Sağlıklı Beslenme ve Obezite Farkındalığ1. Journal of Human Sciences, 17(1), 340-358. doi:10.14687/jhs.v17i1.5944

Gümüs, H. (2009) Yetistirme Yurtlarında Kalan Adolesanların Beslenme ve Fiziksel Aktivite Durumlarının Sağllk ve Vücut Kompozisyonları ile iliskisinin Saptanması, Doktora Tezi, Gazi Üniversitesi, A

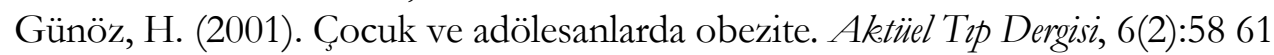

Gür, H. (2000). Çocuklarda fiziksel aktivitenin yeri ve önemi. Bursa Uludağ ü. Tip Fak. Spor Hekimliği Bilim Dali. 6. Spor Bilimleri Kongresi. Ankara: 3-5 Kasım

Hartung D., Stadeler, M., Grieshaber, R., Keller, S., Jahreis, G. (2010). Work and diet related risk factors of cardiovascular diseases: comparison of two occupational groups. J Occup Med Toxicol, 5: 4.

Hooper, D., Coughlan, J., \& Mullen, M. (2008). Structural equation modelling: Guidelines for determining model fit. Articles, 2.

Karasu, Ö.(2006) Yatılı Olan ve Yatlı Olmayan Lise Öğrencilerinin Beslenme Bilgisi ve Durumlarının Değerlendirilmesi, Yüksek Lisans Tezi, Gazi Üniversitesi, Ankara.

Kurtipek, Serkan. "Spor kulüplerine üye bireylerin spor kulübü kavramına ilişkin algılarının belirlenmesi: bir metafor analizi çalışması." spormetre Beden Eğitimi ve Spor Bilimleri Dergisi 17.1: 209-145.

Kusgöz, A. (2005) Pansiyonlu ve Normal Devlet ilköğretim ile Özel ilköğretim Öğrencilerinin Beslenme, Fiziksel Aktivite Alıskanlıkları ve Fiziksel Uygunluklarının Karşılaştırılması, Yüksek Lisans Tezi, Muğla üniversitesi, Muğla

MacCallum, R. C., Browne, M. W., \& Sugawara, H. M. (1996). Power analysis and determination of sample size for covariance structure modeling. Psychological methods, 1(2), 130.

Ostlinning, Freya Elisa (2011), Running for Europe EU Sports Policy and the Role of Civil Society, Unpublished PhD Dissertation, Westphalian Wilhelms University, Münster.

Önder, e \&Aydın, y.(2013) . Obezite Genetiğ Türkiye Klinikleri Journel of endocrinology special topics. 6 (1):13-17

Perez, A. P., Phillips, M. M., Cornell, C. E., Mays, G., Adams, B. (2009). Promoting dietary change among state health employees in arkansas through a worksite wellness program: The Healthy Employee Lifestyle Program (HELP). Preventing Chronic Disease Public Health Research, Practice and Policy, 6(4), www.cdc.gov/pcd/ issues/2009/oct/08_0136.htm (02.04.2010).

Semra İ. (2006) Obez Bireylerde Beslenme, Fiziksel Aktivite ve Sosyal Ozelliklerin Değerlendirilmesi Y.Lisans Tezi, İstanbul Universitesi, İstanbul.

Sunay H. (2003) Türk spor Politikasına Analitik Bir Bakış . Spormetre Beden Eğitimi ve Spor Bilimleri Dergisi , 1, 39-42

Tabachnick, B.G. \& Fidell, L.S. (2013). Using Multivariate Statistics (sixth ed.). Pearson, Boston.

\section{Extended English Summary}

When it comes to sports policy; sports are discussed, principles and objectives, ways and methods of achieving these goals, infrastructure, facilities, equipment and education-teaching approach, national and international perspective on sports, sports organization and implementation philosophy comes to mind (European Commission, 2007b). Turkey "the aim of the sports policy; national sports organization, strengthening and directing the development of athletes can be listed as (Sunay, 2003).

It should be remembered that nutrition is a physiological event as well as a psychological and sociological condition. Otherwise, the concept of obesity would exist alone, and the concept of obesity awareness would not even exist. A healthy society should be composed of healthy people who take care of themselves. The health of the individuals plays a role in the continuation of the development of that society, the achievement of its goals and the achievement of the level of contemporary civilizations. The first step of healthy life in pyramid is proper nutrition. In addition to its role in the growth and development of childhood nutrition, it is also the determinant of the 
health status of the individual in the future life order. Nutrition should never be perceived only as abdominal saturation (Karasu, 2006).

In addition to an unbalanced diet, a proper diet can positively affect the physical and mental development of adolescents. The future health, psychological and even working capacity of the individual is affected by the nutritional habits of adolescents. It can be understood more accurately by using anthropometric measurements in the evaluation of nutrition. A person's BMI level and weight of fat and obesity, weakness can be detected more easily (Silver, 2009).

\section{Purpose and Importance of Research:}

Although there is no determined and serious policy on sports and balanced nutrition in our country, different studies and methods have been tried but the desired success has not been achieved yet. As a result, the number of individuals with obesity and unhealthy body types is increasing day by day and generations away from sports are far from the mental comfort of sports. As a common point of these problems, the health problems of physically and mentally collapsed employees begin and the overall workforce and productivity are declining. We can bring.

\section{Method of Research:}

The population of this study consists of young people aged 16-27 living in Ankara. The sample group consisted of 368 people (218 female $(40.8 \%)$ and 150 male $(59.2 \%)$ ) who volunteered to participate voluntarily among young people aged 16-27 in Ankara. They were selected by random method. At the same time, using the power analysis method, the sample size was determined to be at least 197 in 95\% confidence interval and 80\% power.

\section{Data Analysis:Data collection tools:}

The study group consisted of 368 people (218 female (40.8\%) and 150 male (59.2\%)) who volunteered to participate voluntarily among young people aged 16-27 in Ankara. When the literature is examined, there are different criteria and opinions about the sample size that should be reached in order to perform multivariate analyzes such as factor analysis in the validity studies of the scales. Preacher and MacCallum (2002) stated that the minimum sample size should be between 100 and 250. Other opinions give a ratio depending on the number of items. According to Tavşancil (2002), the sample size should be variable, ie at least 5 times or even 10 times the number of substances. In this study, the sample size is approximately 15 times the number of variables. While the number of OFÖ items was 23 , the sample consisted of 300 students. At the same time, using the power analysis method, the sample size was determined to be at least 197 in 95\% confidence interval and $80 \%$ power.

The data collection tool was filled by a total of 368 young volunteers who resided in Ankara between the ages of 16-27. The data were transferred to computer for evaluation in SPSS package program. Descriptive statistical methods were used in the analysis of demographic information, physical activities, healthy eating levels and obesity awareness levels.

\section{Research Findings:}

When the results of one-way analysis of variance according to income categories were examined, it was found that there was a statistically significant difference in obesity awareness dimension between group averages according to occupational categories. When the Tukey test results were analyzed to determine the significant difference, the difference was "5501TL and over ve $(X 5=3,13)$ with the participants in the income group; "2501-4000 TL" $(X 3=3,98)$ and "40015500 TL" group $(X 3=3,98)$ and "5501TL and above" in favor of the income group has been realized $(\mathrm{F}(4-367)=2.648, \mathrm{p}<.05)$. Nutritional $(\mathrm{F}(4-367)=1,200, \mathrm{p}>.05)$ and physical activity $(\mathrm{F}(4-367)=1.303, \mathrm{p}>.05)$ subscales and the overall scale $(\mathrm{F}(4-367)=1.699, \mathrm{p}>.05)$ in terms of income categories 
It was evaluated whether the scores obtained from obesity awareness scale by gender indicate a statistically significant difference between the groups. According to the results of the T-test, the obesity awareness sub-dimension $(\mathrm{t}(366)=-3.055, \mathrm{p}<, 05)$ and the obesity awareness scale $(\mathrm{t}$ $(366)=-2.141, \mathrm{p}<, 05)$ showed statistically significant differences between the groups. and this situation was realized in favor of female participants. However, it was observed that there was no statistically significant difference in obesity awareness scale in terms of nutrition $(\mathrm{t}(366)=-.947$ $\mathrm{p}>, 05)$ and physical activity $(\mathrm{t}(366)=-.675, \mathrm{p}>, 05)$.

\section{Conclusion, Discussion and Recommendations}

As can be seen in the studies conducted in relation to these; When health behaviors of working individuals compared to non-working individuals of the same age were compared, it was seen that nutrition, physical activity levels and smoking and alcohol consumption rates of working individuals were higher than those who did not work. Business environment; Unhealthy food choice or consumption of workers is closely related to overweight and inadequate levels of physical activity (French, Harnack, Toomey \& Hannan, 2007).

Nutrition forms the basis of health in every period of life for the maintenance of life and protection of health Balanced and good nutrition affects the worker's ability to maintain and even increase the work efficiency and performance at a high level. For an adult to have a healthy and balanced diet, first of all, a healthy BMI and BMI should be maintained at an appropriate level (Perez, Phillips, Cornell, Mays \& Adams, 2009). In this systematic study, obesity is an increasingly common problem in the workplace and among workers, as in the rest of the world. In these studies, employees; it is noteworthy that the rate of being overweight is quite high. It is seen that employees prefer fat-fried foods and carbohydrate foods more in food selection and there is an increase in obesity rates. In addition, body mass index was 30 and above for those who had inadequate physical activity and consumed foods with high fat and carbohydrate content. These values pose a risk for both chronic diseases and mortality. Chronic diseases cannot be directly related to workplace conditions, but workplace risks cannot be ruled out (Hartung, Stadeler, Grieshaber, Keller \& Jahreis, 2010).

These data can be summarized as follows if necessary to contribute to the development of meaningful and reasonable sports policies. The level of decreasing physical activities of young people should be increased. Participation and guidance of girls in physical activity should be ensured. Adequate awareness should be provided for men about obesity. Healthy eating habits should be gained. Necessary information should be given on the effect of physical activity on obesity factor. Regular physical activity should be supported by diet. Young people should be informed that being a healthy individual can be ensured through nutrition and regular and scheduled exercise. Time should be devoted to physical activities not only at leisure but also at certain times of the day. In this way, we hope that our youth will reach the contemporary level with more conscious and healthy generations. 